\title{
SYNTHESIS OF [POLY(2-PYRIDYL)-SUBSTITUTED]-1-AZAAZULENES
}

\author{
Tomoyuki Ariyoshi,, ${ }^{1}$ Tomonori Noda, ${ }^{2}$ Satomi Watarai, ${ }^{3}$ Shoji Tagashira, ${ }^{2}$ \\ Yoshiko Murakami, ${ }^{2}$ Hiroyuki Fujii, ${ }^{4}$ and Noritaka Abe* ${ }^{1}$
}

${ }^{1}$ Graduate School of Medicine, Yamaguchi University, Yoshida, Yamaguchi 753-8512, Japan

${ }^{2}$ Graduate School of Science and Engineering, Yamaguchi University, Yamaguchi 753-8512, Japan

${ }^{3}$ Department of Chemistry, Faculty of Science, Yamaguchi University, Yamaguchi 753-8512, Japan

${ }^{4}$ Science Research Center, Yamaguchi University, Yamaguchi 753-8512, Japan

\begin{abstract}
Pyridyl)-1-azaazulenes were derived from 2-bromo- or 2-iodo-1-azaazulenes and 3-(2-pyridyl)-1-azaazulenes were derived from 3-iodo-1-azaazulenes by Suzuki coupling. Reaction of 3-iodo-1-azaazulenes with B(NPDEA) gave corresponding 3-(2-pyridyl)-1-azaazulenes together with 3-borylated-2-chloor-1-azaazulene (9a) or 3,3'-bi(2-methoxy-1-azaazulene) (10b). Reactions of 8-(2-pyridyl)-1-azaazulene with 2-pyridyllithium gave 4,8-di(2-pyridyl)- and 6,8-di(2-pyridyl)-1-azaazulenes. Reactions of 4,8-di(2-pyridyl)-1-azaazulene with 2-pyridyllithium gave 4,6,8-tri(2-pyridyl)-1-azaazulene. The reactivity of the seven-menbered ring is C8 > C6 > C4. Reaction of 3-(2-pyridyl)-1-azaazulenes with 2-pyridyllithium gave 3,4-di(2-pyridyl)- and 3,8-di(2-pyridyl)-1-azaazulenes.
\end{abstract}

\section{INTRODUCTION}

In the chemistry of 1-azaazulenes, ${ }^{1}$ pyridyl-1-azaazulenes are especially of interest for their physical and chemical properties for comparison with pyridyl-azulenes, ${ }^{2}$ but synthetic reports were few. Recently, we reported the synthesis and some properties of 2-(2-pyridyl)-1-azaazulene (1a) $)^{3}$ and 8-(2-pyridyl)-1-azaazulene (2a,b), ${ }^{4,5}$ which behaved as bidentate ligands. We previously reported that Suzuki coupling of halo-1-azaazulene is suitable for introducing aryl group on five-membered ring of 1-azaazulene, ${ }^{4}$ and the addition-dehydrogenation reaction of aryllithium is good method for introducing aryl groups to 8-position of 1-azaazulenes. ${ }^{4}$ Therefore, for synthesis of poly(2-pyridyl)-1-azaazulenes, we exploited the combination of Suzuki coupling and the addition-dehydration reaction of 2-pyridyllithium with (2-pyridyl)-1-azaazulenes.

† Dedicated to Dr. Keiichiro Fukumoto on occasion of his 75th birthday. 


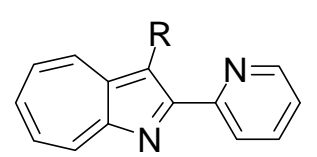

$1 \mathrm{a}: \mathrm{R}=\mathrm{H}$

$1 \mathrm{~b}: \mathrm{R}=\mathrm{Me}$

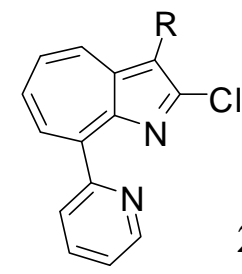

2a : $\mathrm{R}=\mathrm{H}$

$2 \mathbf{b}: \mathrm{R}=\mathrm{CO}_{2} \mathrm{Et}$

\section{RESULTS AND DISCUSSION}

Reaction of 2-chloro-1-azaazulene (3a) did not undergo Suzuki coupling. Reaction of 2-bromo-1-azaazulene (3b) with pyridineboronic acid $N$-phenyl-diethylamine ester (B(NPDEA)) in the presence of $\mathrm{PdCl}_{2}\left(\mathrm{PPh}_{3}\right)_{2}$, CuI, and $\mathrm{K}_{2} \mathrm{CO}_{3}$ in dry THF under heating for $24 \mathrm{~h}$ at $80{ }^{\circ} \mathrm{C}$ in a sealed tube gave a 2-(2-pyridyl)-1-azaazulene-Cu complex. Using $\mathrm{Cs}_{2} \mathrm{CO}_{3}$ as base in the reaction gave similar result. Treatment of the complex with aq. Solution of EDTA gave free 2-(2-pyridyl)-1-azaazulene (1a) (23\%) together with recovered $\mathbf{3 b}(14 \%)$. When the reaction was carried out using 2-iodo-1-azaazulene (3c), which was produced in 66\% yield by the treatment of $\mathbf{3 b}$ with Mg-metal and $\mathrm{I}_{2}$, the yield was slightly raised to 25\%. Similar reaction of 2-bromo-3-methyl-1-azaazulene (3d) with B(NPDEA) gave 3-methyl-2-(2-pyridyl)-1-azaazulene (1b) (12\%).

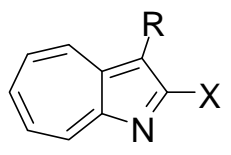

3a : $\mathrm{R}=\mathrm{H}, \mathrm{X}=\mathrm{Cl}$

3b : $\mathrm{R}=\mathrm{H}, \mathrm{X}=\mathrm{Br}$

3c: $\mathrm{R}=\mathrm{H}, \mathrm{X}=\mathrm{I}$

3d : $\mathrm{R}=\mathrm{Me}, \mathrm{X}=\mathrm{Br}$

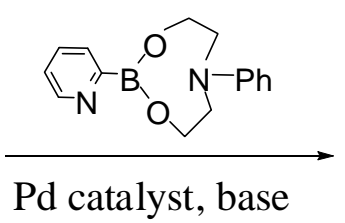

Pd catalyst, base

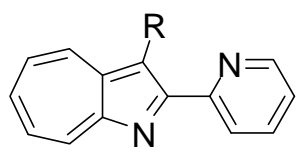

1a : $\mathrm{R}=\mathrm{H}$

$1 \mathrm{~b}: \mathrm{R}=\mathrm{Me}$<smiles></smiles>

$3 \mathbf{b}$

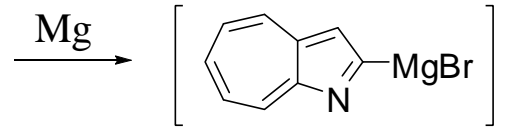

$\mathrm{N}$

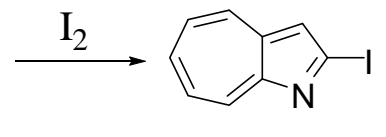

3c

Treatment of 2-chloro-8-(2-pyridyl)-1-azaazulene (2a) with an equivalent molar of 2-pyridyllithium (PyLi) followed by MeOH gave only recovered (2a) in over $80 \%$ yield. Treatment of 2a with excess molar of PyLi (2.4 eq. mole) at $-80{ }^{\circ} \mathrm{C}$ for $0.5 \mathrm{~h}$ followed by $\mathrm{MeOH}$ gave addition products, and a successive dehydrogenation of the intermediates with tetrachloro-o-benzoquinone (o-chloranil) at $50{ }^{\circ} \mathrm{C}$ for $\quad 17 \quad \mathrm{~h}$ afforded 2-chloro-6,8-di(2-pyridyl)-1-azaazulene (4) and 2-chloro-4,8-di(2-pyridyl)-1-azaazulene (5) in 58\% and 4\% yields, respectively. Reaction of 5 with PyLi under similar conditions to that descrived above gave 2-chloro-4,6,8-tri(2-pyridyl)-1-azaazulene (6) in 68\% yield. Further treatment of 6 with an excess equivalent of PyLi proceeded but only unstable yellow tar was obtained in spite of the treatment with o-chloranil at $50{ }^{\circ} \mathrm{C}$ for $6 \mathrm{~d}$, along with recovered (6) (4\%). In the reaction, the addition reaction would undergo but successive dehydrogenation would be prevented, being ascribable to the steric hindrance. The results showed that the reactivity of the seven-menbered ring is $\mathrm{C} 8>\mathrm{C} 6>\mathrm{C} 4$. 
In the similar manner, we examined of 1a with PyLi, but the reaction did not undergo and 1a (97\%) was recovered. Chelation of $\mathrm{Li}^{+}$with $\mathbf{1 a}$ would keep apart the pyridyl moiety from seven-membered ring and this would cause to prevent the reaction.

The structures of obtained products were deduced by spectroscopic data as well as elemental analysis. Electronic spectra of 3a, 2a, 4, and $\mathbf{6}$ were shown in Fig. 1. It is shown that introduction of pyridine on 1-azaazulene nuclei caused bathochromic shift.
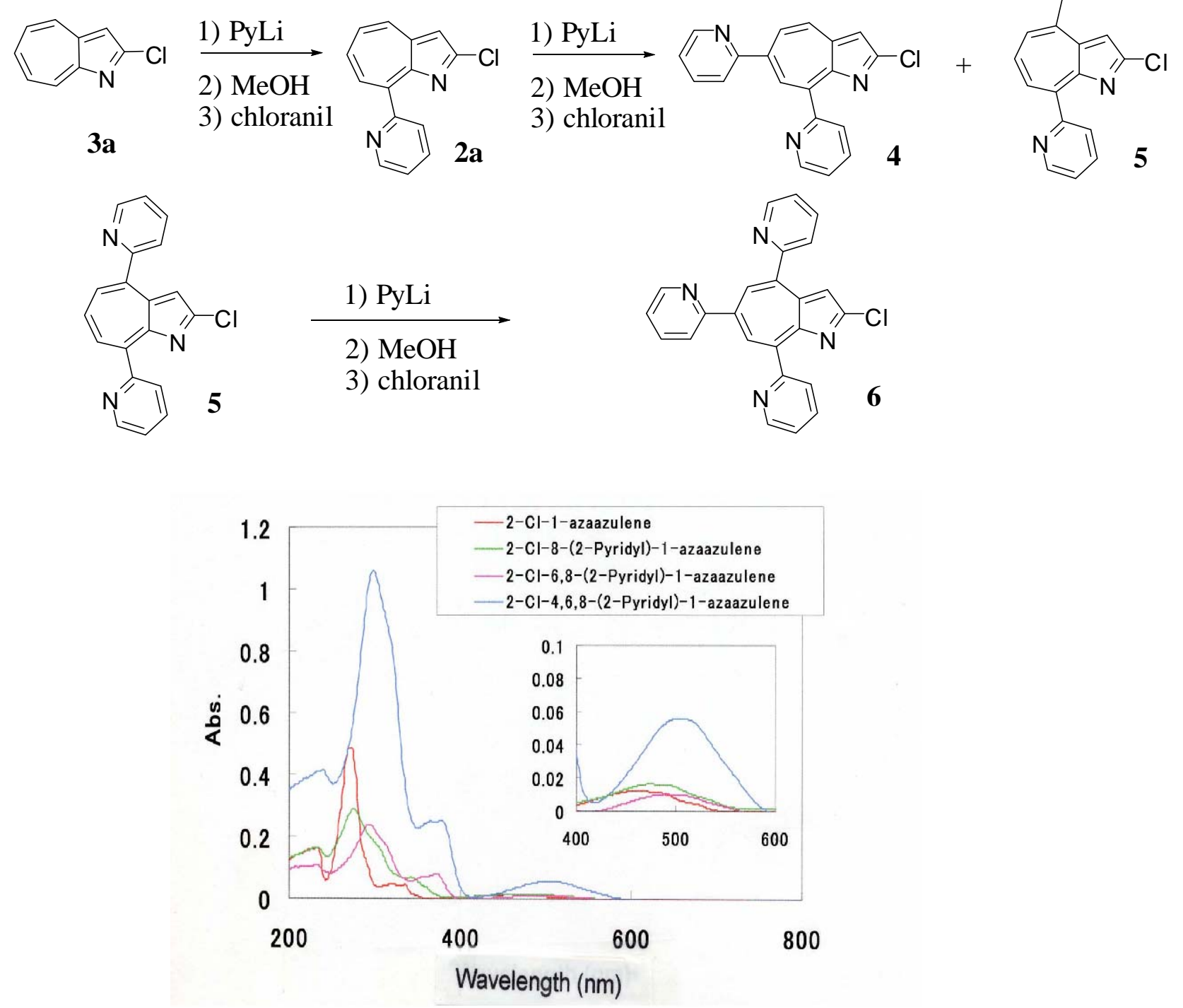

Figure 1. Electronic spectra of pyridyl-1-azaazulenes

Reaction of 2-chloro-3-iodo-1-azaazulene (7a) with $\mathrm{B}(\mathrm{NPDEA})$ in the presence of $\mathrm{PPh}_{3}, \mathrm{Pd}(\mathrm{OAc})_{2}$, $\mathrm{K}_{2} \mathrm{CO}_{3}$, and $\mathrm{CuI}$ in dry THF under heating for $24 \mathrm{~h}$ at $80{ }^{\circ} \mathrm{C}$ in a sealed tube gave 2-chloro-3-(2-pyridyl)-1-azaazulene

(8a) $(50 \%)$ together with

(2-chloro-1-azaazulen-3-yl)-(2-pyridyl)-[ $N$-(2-hydroxylethyl)]-( $N$-phenyl)aminoethylborate (9a) (3\%). Similar treatment of 3-iodo-2-methoxy-1-azaazulene (7b) with B(NPDEA) in the presence of $\mathrm{PdCl}_{2}\left(\mathrm{PPh}_{3}\right)_{2}, \mathrm{~K}_{2} \mathrm{CO}_{3}$, and $\mathrm{CuI}$ in dry THF under heating for $3 \mathrm{~h}$ at $80{ }^{\circ} \mathrm{C}$ in a sealed tube gave 2-methoxy-3-(2-pyridyl)-1-azaazulene (8b) (84\%) together with 3,3'-bi(2-methoxy-1-azaazulene) (10b) 
$(6 \%)$.

We previously reported that reaction of 7a with bis(pinacolato)diborane gave $\mathbf{1 1}$ and 10a. Therefore, it is thought that $\mathbf{9}$ would be produced by the reaction of $\mathbf{7}$ and B(NPDEA). Successive reaction of $\mathbf{9 b}$ and $\mathbf{7 b}$ would produce $\mathbf{1 0 b}$ under the conditions. Lower reactivity of $\mathbf{9 a}$ than $\mathbf{9 b}$ and $\mathbf{1 1}$ would cause to give none of 10a.

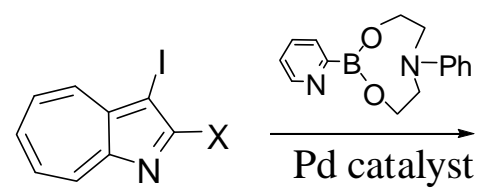

7a : $\mathrm{X}=\mathrm{Cl}$

7b : $\mathrm{X}=\mathrm{OMe}$

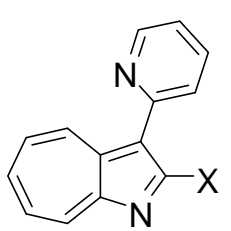

8a : $\mathrm{X}=\mathrm{Cl}$

8b : $\mathrm{X}=\mathrm{OMe}$

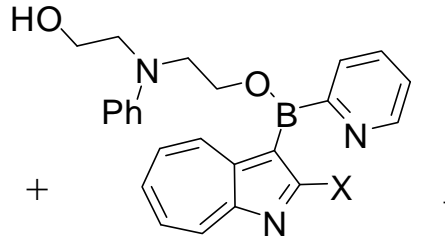

9a: $\mathrm{X}=\mathrm{Cl}$

9b: $\mathrm{X}=\mathrm{OMe}$

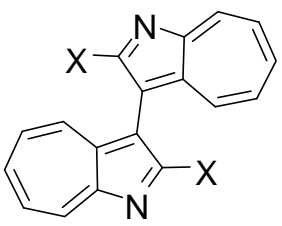

10a : $\mathrm{X}=\mathrm{Cl}$

10b : $\mathrm{X}=\mathrm{OMe}$

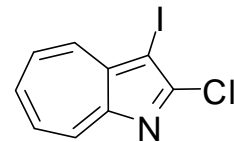

$7 a$

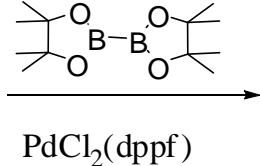

$\operatorname{PdCl}_{2}(\mathrm{dppf})$

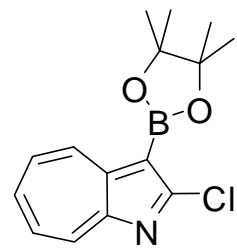

11<smiles>Clc1[nH]c2ccccc2c1-c1c(Cl)[nH]c2ccccc12</smiles>

$10 a$

We examined the following reaction of $\mathbf{8}$ with PyLi similarly. Treatment of $\mathbf{8 a}$ with PyLi followed by quenching with $\mathrm{MeOH}$ and successive dehydrogenation gave a mixture of 12a (30\%), 13a (30\%), 12b (7\%), and 13b (9\%). Compounds 12b and 13b would form via a substitution of 12a and 13a by methoxide. Existence of aryl group at C-3 would enhance the reactivity of C-2. ${ }^{4}$ Similar reaction of $\mathbf{8 b}$ with PyLi gave 12b (26\%) and 13b (30\%). In these reactions, attacks of PyLi at C-4 and C-8 of 1-azaazulene nuclei were practically equal, and 3,6-di(2-pyridyl)-1-azaazulenes were not obtained. Coordination of electropositive lithium atom of the reagent on nitrogen atoms of 1-azaazulene and pyridine is thought to controll the reaction position.<smiles>[X]c1[nH]c2ccccc2c1-c1ccccn1</smiles>

1) PyLi

2) $\mathrm{MeOH}$

3) chloranil

8a : $\mathrm{X}=\mathrm{Cl}$

8b $: \mathrm{X}=\mathrm{OMe}$

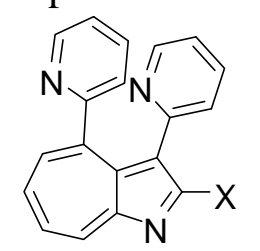

12a : $\mathrm{X}=\mathrm{Cl}$

12b : $\mathrm{X}=\mathrm{OMe}$

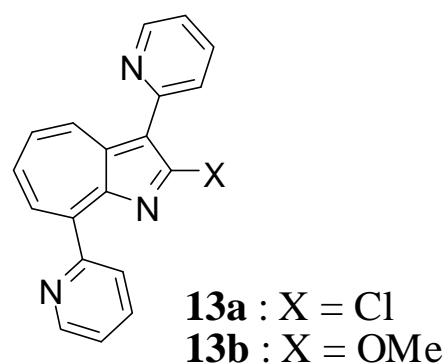

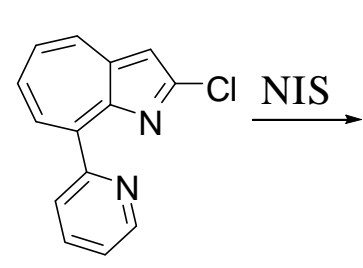

2a

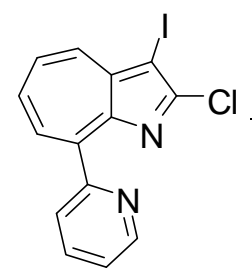

14

To expect the formation of 13a, we performed Suzuki coupling of 14. In the reaction, only insoluble 
dark material, which was considered to be 14-Cu complex, was precipitated. Previously, we reported about the formation of Cu-complex with $2 \mathbf{a}^{4}{ }^{4}$

\section{ACKNOWLEDGEMENTS}

This work was partially supported by a Grant-in-Aid for Scientific Research (No.18510075) to S. T. from the Japan Society for Promotion of Science (JSPS).

\section{EXPERIMENTAL}

Mps were measured using a Yanagimoto micro-melting apparatus and uncorrected. ${ }^{1} \mathrm{H}$ NMR spectra (including $\mathrm{HH}-\mathrm{COSY}$ and $\mathrm{CH}-\mathrm{COSY} \mathrm{NMR}$ ) were recorded on a Bruker AVANCE 400S (400 MHz) and ${ }^{13} \mathrm{C}$ NMR spectra were recorded on a Bruker AVANCE 400S (100.6 MHz) using $\mathrm{CDCl}_{3}$ as a solvent with tetramethylsilane as an internal standard unless otherwise stated; $J$ values are recorded in $\mathrm{Hz}$. IR spectra were recorded for KBr pellets on a Nicolet FT-IR Avatar 370DTGS. Electronic spectra were recorded with JASCO V-670 spectrophotometer using $\mathrm{CHCl}_{3}$ as a solvent. MS spectra were taken with an LC-MS Waters Integrity System. Elemental analyses were taken with a Perkin Elmer 2400II. Kieselgel 60 was used for column chromatography and Kieselgel 60G was used for thin-layer chromatography.

\section{Synthesis of 2-iodo-1-azaazulene (3c)}

Under argon atmosphere, Mg (0.032 g, $1.3 \mathrm{mmol})$ was activated by stirring overnight with small amounts of iodine. A mixture of the $\mathrm{Mg}$, iodine $(0.300 \mathrm{~g}, 1.2 \mathrm{mmol})$, and 2-bromo-1-azaazulene (3b) ( $0.207 \mathrm{~g}, 1.0 \mathrm{mmol})$ in dry THF $(20 \mathrm{~mL})$ was heated at $80{ }^{\circ} \mathrm{C}$ for $5 \mathrm{~h}$. To the mixture was added water $(30 \mathrm{ml})$, then the mixture was extracted with $\mathrm{CHCl}_{3}$. The extract was dried over sodium sulfate and evaporated. Chromatography of the residue with hexane- $\mathrm{CHCl}_{3}(1: 1)$ gave 2-iodo-1-azaazulene (3c) (0.177 g, 66\%).

3c: Red needles (from hexane- $\mathrm{CH}_{2} \mathrm{Cl}_{2}$ ), mp $71-74{ }^{\circ} \mathrm{C}: \delta_{\mathrm{H}} 7.56(1 \mathrm{H}, \mathrm{s}, \mathrm{H}-3), 7.68(1 \mathrm{H}, \mathrm{dd}, J 9.9$ and 9.7, H-7), 7.77 (1H, t, J 9.9, H-5), 7.93 (1H, t, J 9.9, H-6), 8.51 (1H, d, J 9.9, H-4), and 8.66 (1H, d, $J$ 9.7, $\mathrm{H}-8) ; \mathrm{m} / \mathrm{z}$ (rel intensity) 255 ( $\left.\mathrm{M}^{+}, 100\right), 207$ (8), 128 (39), 127 (21), 101 (44), and 77 (25). Anal. Calcd for $\mathrm{C}_{9} \mathrm{H}_{6} \mathrm{NI}$ : C, 42.38; H, 2.37; N, 5.49. Found: C, 42.53; H, 2.29; N, 5.33.

\section{Synthesis of 2-(2-pyridyl)-1-azaazulene}

A) Under argon atmosphere, a mixture of $3 \mathbf{b}(0.104 \mathrm{~g}, 0.50 \mathrm{mmol})$, pyridineboronic acid $N$-phenyldiethylamine ester (B(NPDEA)) (0.402 g, $1.5 \mathrm{mmol}), \mathrm{PdCl}_{2}\left(\mathrm{PPh}_{3}\right)_{2}(0.0175 \mathrm{~g}, 0.025 \mathrm{mmol}, 5$ mol\%), CuI (0.280 g, $1.5 \mathrm{mmol}), \mathrm{K}_{2} \mathrm{CO}_{3}(0.138 \mathrm{~g}, 1,0 \mathrm{mmol})$ in THF (20 mL) was stirred for $4 \mathrm{~h}$ at $80^{\circ} \mathrm{C}$. The precipitate was collected by filtration and washed with water and $\mathrm{CHCl}_{3}$. The precipitate was suspended in EDTA (1.0 g, $2.5 \mathrm{mmol})$ and water $(10 \mathrm{~mL})$, then the suspension was stirred for $24 \mathrm{~h}$ at $80^{\circ} \mathrm{C}$. The suspension was combined with the filtrate and washed solution, and the mixture was extracted with $\mathrm{CHCl}_{3}$. The extract was dried over $\mathrm{Na}_{2} \mathrm{SO}_{4}$ and evaporated. The residue was chromatographed on silica gel column with hexane- $\mathrm{CHCl}_{3}(1: 1)$ to give 2-(2-pyridyl)-1-azaazulene ${ }^{3}$ (1a) $(0.024 \mathrm{~g}, 23 \%)$ and recovered $3 \mathbf{b}(0.015 \mathrm{~g}, 14 \%)$. 
B) Under argon atmosphere, a mixture of 3c (0.1335 g, $0.50 \mathrm{mmol}), \mathrm{B}(\mathrm{NPDEA})(0.400 \mathrm{~g}, 1.5 \mathrm{mmol})$, $\mathrm{PdCl}_{2}\left(\mathrm{PPh}_{3}\right)_{2}$ (0.0175 g, $0.025 \mathrm{mmol}, 5 \mathrm{~mol} \%$ )、CuI (0.285 g, $\left.1.5 \mathrm{mmol}\right), \mathrm{Cs}_{2} \mathrm{CO}_{3}$ (0.243 g, $\left.0.75 \mathrm{mmol}\right)$ in THF $(10 \mathrm{~mL})$ was stirred for $4 \mathrm{~h}$ at $80^{\circ} \mathrm{C}$. The precipitate was collected by filtration and washed with water and $\mathrm{CHCl}_{3}$. The precipitate was suspended in EDTA (1.0 g, $\left.2.5 \mathrm{mmol}\right)$ and water $(10 \mathrm{~mL})$, then the suspension was stirred for $24 \mathrm{~h}$ at $80^{\circ} \mathrm{C}$. The suspension was combined with the filtrate and washed solution, and the mixture was extracted with $\mathrm{CHCl}_{3}$. The extract was dried over $\mathrm{Na}_{2} \mathrm{SO}_{4}$ and evaporated. The residue was chromatographed on silica gel column with hexane- $\mathrm{CHCl}_{3}(1: 1)$ to give $1 \mathrm{a}(0.025 \mathrm{~g}, 25 \%)$.

In the similar manner, 3-methyl-2-(2-pyridyl)-1-azaazulene (1b) was obtained in 12\%.

1b: Red violet powders (from hexane- $\mathrm{CH}_{2} \mathrm{Cl}_{2}$ ), mp 86-89 ${ }^{\circ} \mathrm{C}:{ }^{1} \mathrm{H}$ NMR $\delta 2.96(3 \mathrm{H}, \mathrm{s}, \mathrm{Me}), 7.31(1 \mathrm{H}$, ddd, $J$ 7.7, 4.7, and 1.0, H-5'), 7.60 (1H, dd, $J 9.9$ and $9.8 \mathrm{H}-5$ ), 7.69 (1H, dd, $J 9.8$ and 9.6, H-7), 7.81 (1H, t, $J$ 9.8, H-6), 7.85 (1H, ddd, $J$ 7.9, 7.5, and 0.9, H-4'), 8.47 (1H, dd, $J 7.9$ and 1.0, H-3'), 8.48 (1H, d, $J$ 9.9, H-4), 8.67 (1H, d, $J$ 9.6, H-8), and 8.81 (1H, dd, $J 4.7$ and 0.7, H-6'): ${ }^{13} \mathrm{C}$ NMR $\delta 11.12,122.13$, 123.00, 124.76, 127.26, 128.76, 134.15, 136.17, 136.41, 137.58, 145.83, 149.46, 155.78, 157.22, and 162.81. Anal. Calcd for $\mathrm{C}_{15} \mathrm{H}_{12} \mathrm{~N}_{2}$ : C, 81.79; H, 5.49; N, 12.72. Found: C, 81.55; H, 5.45; N, 12.59 .

\section{Reaction of 2-chloro-3-iodo-1-azaazulene (7a) with B(NPDEA)}

Under argon atmosphere, a mixture of 7a (0.288 g, 1.00 mmol), B(NPDEA) (0.800 g, 3.00 mmol), $\mathrm{PPh}_{3}$ (0.053 g, $0.20 \mathrm{mmol}$ ), $\mathrm{Pd}(\mathrm{OAc})_{2}$ (0.011 g, $0.02 \mathrm{mmol}$, 5mol\%), CuI (0.570 g, $3.00 \mathrm{mmol}$ ), and $\mathrm{K}_{2} \mathrm{CO}_{3}$ $(0.276 \mathrm{~g}, 2.00 \mathrm{mmol})$ in dry THF $(20 \mathrm{~mL})$ was heated for $24 \mathrm{~h}$ at $80{ }^{\circ} \mathrm{C}$ in a sealed tube. The mixture was poured into water and extracted with $\mathrm{CHCl}_{3}$. The extract was dried over $\mathrm{Na}_{2} \mathrm{SO}_{4}$ and evaporated. The residue was chromatographed on silica gel column with hexane-EtOAc $(5: 3)$ to give 2-chloro-3-(2-pyridyl)-1-azaazulene (8a)

$(0.122$

g, $50 \%)$ and

(2-chloro-1-azaazulen-3-yl)-(2-pyridyl)-[N-

(2-hydroxylethyl)]-( $N$-phenyl)aminoethylborate (9a) (0.012 g, 3\%).

8a: Orange needles (from hexane- $\mathrm{CH}_{2} \mathrm{Cl}_{2}$ ), mp 127-129 ${ }^{\circ} \mathrm{C}$ : ${ }^{1} \mathrm{H}$ NMR $\delta_{\mathrm{H}} 7.30(1 \mathrm{H}$, ddd, $J$ 7.9, 4.9, and 1.5, H-5'), 7.77 (1H, dd, $J 10.1$ and 9.8, H-5), 7.83 (1H, dd, $J 10.8$ and 9.7, H-7), 7.86 (1H, ddd, $J$ 7.3, 1.5, and 0.9, H-3'), 7.92 (1H, ddd, $J$ 7.9, 7.3, and 1.7, H-4'), 7.97 (1H, ddd, $J$ 10.8, 9.8, and 0.9, H-6), 8.66 (1H, dd, $J 9.7$ and 0.9, H-8), 8.81 (1H, ddd, $J$ 4.9, 1.7 and 0.9, H-6'), and 9.21 (1H, d, $J$ 10.1, H-4):

${ }^{13} \mathrm{C}$ NMR $\delta 121.76,121.81,125.03,130.92,131.16,136.31,136.50,136.60,139.11,144.15,149.69$, 152.27, 155.49, and 155.92; $\lambda_{\max } \mathrm{nm}$ ( $\log \varepsilon$ ) 280 (4.56), 299 (4.60), 330 (3.91), 363 (3.81), and 483 (3.09). Anal. Calcd for $\mathrm{C}_{14} \mathrm{H}_{9} \mathrm{~N}_{2} \mathrm{Cl}$ : C, 69.86; H, 3.77; N, 11.64. Found: C, 69.63; H, 4.05; N, 11.59. 9a: Orange powders (from hexane- $\mathrm{CH}_{2} \mathrm{Cl}_{2}$ ), mp 137-138 ${ }^{\circ} \mathrm{C}:{ }^{1} \mathrm{H}$ NMR $\delta 3.62$ (2H, d, $J 5.1, \mathrm{NCH}_{2}$ ), 3.83 (2H, t, $J$ 5.1, $\mathrm{NCH}_{2}$ ), 3.92, (2H, t, $J$ 5.7, $\left.\mathrm{OCH}_{2}\right), 4.60$ (1H, br s, OH), 5.03 (2H, t, $J$ 5.7, $\left.\mathrm{OCH}_{2}\right), 6.64(1 \mathrm{H}$, t, $J$ 7.2, H-p-phenyl), 6.82 (2H, d, $J$ 8.8, H-o-phenyl), 7.11 (2H, dd, $J 8.8$ and 7.2, H-m-phenyl), 7.18 (1H, ddd, $J$ 7.5, 4.9, and 1.1, H-Py-4), 7.55-7.65 (3H, m, H-5, 6, and 7), 7.76 (1H, ddd, $J$ 8.0, 7.5, and 1.8, H-Py-5), 7.93 (1H, ddd, $J$ 8.0, 1.1, and 0.9, H-Py-3), 8.25-8.30 (1H, m, H-8), 8.74 (1H, ddd, $J$ 4.9, 1.8, and 0.9, H-Py-6), and 9.35 (1H, dm, J 10.9, H-4): ${ }^{13} \mathrm{C}$ NMR $\delta 52.07,55.17,60.09,109.57,112.81$, 116.99, 119.66, 123.83, 129.13, 130.74, 131.02, 131.21, 133.07, 134.81, 136.21, 144.37, 148.24, 149.22, 
153.23, 155.00, and 172.10; $\lambda_{\max } \mathrm{nm}$ (log $\varepsilon$ ) 284 (4.57), 306 (4.58), 314 (4.58), 375 (3.85, sh), 387 (3.86), and 461 (3.37). Anal. Calcd for $\mathrm{C}_{24} \mathrm{H}_{23} \mathrm{~N}_{3} \mathrm{O}_{2} \mathrm{BCl}$ : C, 66.77; H, 5.37; N, 9.73. Found: C, 66.29; H, 5.28; N, 9.55.

\section{Reaction of 3-iodo-2-methoxy-1-azaazulene (7b) with B(NPDEA)}

Under argon atmosphere, a mixture of $7 \mathbf{b}(0.143 \mathrm{~g}, 0.50 \mathrm{mmol})$, B(NPDEA) (0.400 g, $1.00 \mathrm{mmol})$, CuI (0.286 g, $1.00 \mathrm{mmol}$ ), $\mathrm{PdCl}_{2}\left(\mathrm{PPh}_{3}\right)_{2}\left(0.018 \mathrm{~g}, 0.026 \mathrm{mmol}, 5 \mathrm{~mol} \%\right.$ ), and $\mathrm{K}_{2} \mathrm{CO}_{3}(0.140 \mathrm{~g}, 1.0 \mathrm{mmol})$ in dry THF (15 mL) was heated for $3 \mathrm{~h}$ at $80{ }^{\circ} \mathrm{C}$ in a sealed tube. Then the solvent was evaporated. The residue was chromatographed on silica gel column with hexane- $\mathrm{CHCl}_{3}(1: 1)$ to give $\mathbf{8 b}(0.099 \mathrm{~g}$, 84\%) and 3,3'-bis(2-methoxy-1-azaazulene) (10b) (0.0045 g, 6\%).

8b: Red prisms (from hexane- $\mathrm{CH}_{2} \mathrm{Cl}_{2}$ ), mp 88-89 ${ }^{\circ} \mathrm{C}:{ }^{1} \mathrm{H}$ NMR $\delta 4.36\left(3 \mathrm{H}, \mathrm{s}, \mathrm{OCH}_{3}\right), 7.13(1 \mathrm{H}$, dd, $J$ 7.2, and 4.6, H-5'), 7.50-7.61 (3H, m, H-5,6,7), 7.73 (1H, td, $J 8.1$ and $7.2, \mathrm{H}-4$ '), 7.99 (1H, d, $J$ 8.1, H-3'), 8.27-8.33 (1H, m, H-8), 8.74 (1H, d, $J$ 4.6, H-6'), and 9.43-9.52 (1H, m, H-4): ${ }^{13} \mathrm{C}$ NMR $\delta 56.58$, 109.54, 120.46, 123.67, 130.42, 130.80, 131.21, 133.08, 134.52, 136.10, 144.47, 149.15, 153.53, 155.61, and 173.18; $\lambda_{\max } \mathrm{nm}(\log \varepsilon) 285$ (4.53), 308 (4.57, sh), 315 (4.60), and 461 (3.41). Anal. Calcd for $\mathrm{C}_{15} \mathrm{H}_{12} \mathrm{~N}_{2} \mathrm{O}$ : C, 76.25; H, 5.12; N, 11.86. Found: C, 76.15; H, 5.28; N, 11.80.

10b: Red prisms (from hexane- $\mathrm{CH}_{2} \mathrm{Cl}_{2}$ ), mp 223-225 ${ }^{\circ} \mathrm{C}$ : ${ }^{1} \mathrm{H}$ NMR $\delta 4.30\left(6 \mathrm{H}, \mathrm{s}, \mathrm{OCH}_{3}\right), 7.39(2 \mathrm{H}$, dddd, $J$ 10.4, 9.8,1.2 and 0.9, H-5,5'), 7.54 (2H, ddd, $J$ 9.8, 9.2 and 0.6, H-7,7'), 7.60 (2H, dd, $J 9.9$ and 9.8, H-6,6'), 7.86 (2H, dd, J 9.2 and 0.6, H-4,4'), and 8.29 (1H, dd, $J 10.4$ and 1.2, H-8,8'). Anal. Calcd for $\mathrm{C}_{20} \mathrm{H}_{16} \mathrm{~N}_{2} \mathrm{O}_{2}$ : C, 75.93; H, 5.10; N, 8.86. Found: C, 75.88; H, 5.22; N, 8.60.

\section{Reaction of 2-chloro-8-(2-pyridyl)-1-azaazulene (2a) with 2-pyridyllithium}

Under argon atmosphere, $1.5 \mathrm{M}$ butyllithium $(1.7 \mathrm{~mL}, 2.60 \mathrm{mmol})$ was added to the solution of 2-bromopyridine $(0.23 \mathrm{~mL}, 2.40 \mathrm{mmol})$ in dry THF $(15 \mathrm{~mL})$ at $-90{ }^{\circ} \mathrm{C}$. To the mixture $2 \mathbf{a}(0.240 \mathrm{~g}$, $1.00 \mathrm{mmol})$ in dry THF $(15 \mathrm{~mL})$ was added, and the mixture was stirred for $15 \mathrm{~min}$ at $-80{ }^{\circ} \mathrm{C}$, then $\mathrm{MeOH}(10 \mathrm{~mL})$ was added. After the mixture was warm to $\mathrm{rt}, o$-chloranil $(0.260 \mathrm{~g}, 2.4 \mathrm{mmol})$ was added to the mixture and the mixture was stirred for $17 \mathrm{~h}$ at $50{ }^{\circ} \mathrm{C}$. The mixture was poured into water and extracted with $\mathrm{CHCl}_{3}$. The extract was dried over $\mathrm{Na}_{2} \mathrm{SO}_{4}$, and evaporated. The residue was chromatographed on silica gel column with ACOEt-hexane (2 : 5) to give 2-chloro-6,8-bis(2-pyridyl)-1azaazulene (4) (0.185 g, 58\%) and 2-chloro-4,8-bis(2-pyridyl)-1-azaazulene (5) (0.013 g, 4\%).

4: Orange needles (from hexane- $\mathrm{CH}_{2} \mathrm{Cl}_{2}$ ), mp 168-170 ${ }^{\circ} \mathrm{C}:{ }^{1} \mathrm{H}$ NMR $\delta 7.31(1 \mathrm{H}, \mathrm{s}, \mathrm{H}-3), 7.36(1 \mathrm{H}$, ddd, $J$ 7.5, 4.7, and 1.1, H-5'’), 7.39 (1H, ddd, $J$ 7.3, 4.8, and 1.3, H-5'), 7.82 (1H, dd, $J 8.0$ and 7.5, H-4'’), 7.87 (1H, dd, $J 7.9$ and 7.3, H-4'), 7.93 (1H, dd, $J 8.0$ and 1.1, H-3’’), 8.30 (1H, dd, $J 7.9$ and 1.3, H-3'), 8.36 (1H, dd, $J 10.4$ and 1.9, H-5), 8.57 (1H, d, $J$ 10.4, H-4), 8.78 (1H, d, $J$ 4.7, H-6’'), 8.81 (1H, d, $J$ 4.8 , H-6'), and 8.91 (1H, s, H-7): ${ }^{13} \mathrm{C}$ NMR $\delta 113.49,123.54,123.86,129.05,129.72,134.08,134.30$, 136.19, 137.58, 145.09, 148.15, 148.22, 150.08, 150.32, 152.71, 158.86, 158.52, and 159.94; $\lambda_{\max } \mathrm{nm}$ (log $\varepsilon) 294$ (4.38), 358 (3.84), 372 (3.89), and 492 (3.00). Anal. Calcd for $\mathrm{C}_{19} \mathrm{H}_{12} \mathrm{~N}_{3} \mathrm{Cl}: \mathrm{C}, 71.81 ; \mathrm{H}$, 3.81; N, 12.98. Found: C, 71.80; H, 4.12; N, 12.93 .

5: Orange brown needles (from hexane- $\mathrm{CH}_{2} \mathrm{Cl}_{2}$ ), mp $168-170{ }^{\circ} \mathrm{C}:{ }^{1} \mathrm{H}$ NMR $\delta 7.18(1 \mathrm{H}, \mathrm{s}, \mathrm{H}-3), 7.40$ (1H, ddd, $J$ 7.5, 4.8, and 0.8, H-5'), 7.46 (1H, ddd, $J$ 7.6, 4.8, and 0.8, H-5’’), 7.75 (1H, dd, $J$ 7.8 and 0.8, 
H-3’’), 7.87 (1H, d, J 9.7 H-5), 7.88 (1H, ddd $J$ 7.9, 7.5 and 1.9, H-4'), 7.91 (1H, ddd, $J$ 7.8, 7.6 and 1.7, H-4’'), 8.04 (1H, dd, $J 10.8$ and 9.7, H-6), 8.27 (1H, dd, $J 7.9$ and 0.8, H-3’), 8.33 (1H, d, $J$ 10.8, H-7), 8.82 (1H, dd, $J 4.8$ and 1.9, H-6'), and 8.85 (1H, dd, $J 4.8$ and 1.7, H-6'”): ${ }^{13} \mathrm{C}$ NMR $\delta 112.71,123.47$, 123.54, 124.72, 129.05, 128.76, 131.68, 133.20, 135.75, 136.12, 136.72, 146.06, 146.26, 146.43, 149.63, 150.07, 153.58, 157.35, 157.89, and 159.47; $\lambda_{\max } \mathrm{nm}$ (log $\varepsilon$ ) 286 (4.63), 348 (3.80, sh), and 494 (3.30). Anal. Calcd for $\mathrm{C}_{19} \mathrm{H}_{12} \mathrm{~N}_{3} \mathrm{Cl}$ : C, 71.81; H, 3.81; N, 12.98. Found: C, 71.88; H, 4.02; N, 12.89 .

\section{Reaction of 2-chloro-4,8-di(2-pyridyl)-1-azaazulene (5) with 2-pyridyllithium}

Under argon atmosphere, $1.5 \mathrm{M}$ butyllithium $(1.25 \mathrm{~mL}, 1.95 \mathrm{mmol})$ was added to the solution of 2-bromopyridine $(0.172 \mathrm{~mL}, 1.80 \mathrm{mmol})$ in dry THF $(15 \mathrm{~mL})$ at $-90{ }^{\circ} \mathrm{C}$, and the mixture was stirred for $30 \mathrm{~min}$. To the mixture 5 (0.160 g, $0.50 \mathrm{mmol})$ in dry THF $(15 \mathrm{~mL})$ was added, and the mixture was stirred for $30 \mathrm{~min}$ at $-80{ }^{\circ} \mathrm{C}$, then $\mathrm{MeOH}(10 \mathrm{~mL})$ was added. After the mixture was warm to rt, o-chloranil (0.260 g, $2.4 \mathrm{mmol}$ ) was added to the mixture and the mixture was stirred for $17 \mathrm{~h}$ at $50{ }^{\circ} \mathrm{C}$. The mixture was poured into water and extracted with $\mathrm{CHCl}_{3}$. The extract was dried over $\mathrm{Na}_{2} \mathrm{SO}_{4}$, and evaporated. The residue was chromatographed on silica gel column with EtOAc-hexane $(1: 1)$ to give 2-chloro-4,6,8-tris(2-pyridyl)-1-azaazulene (6) (0.134 g, 68\%).

6: Orange needles (from hexane- $\mathrm{CH}_{2} \mathrm{Cl}_{2}$ ), mp 211-214 ${ }^{\circ} \mathrm{C}:{ }^{1} \mathrm{H} \mathrm{NMR} \delta 7.18(1 \mathrm{H}, \mathrm{s}, \mathrm{H}-3), 7.33(1 \mathrm{H}$, ddd, $J$ 7.8, 4.8, and 1.0, H-5','), 7.40 (1H, ddd, $J$ 7.9, 5.0, and 1.1, H-5'”), 7.45 (1H, ddd, $J$ 7.8, 4.9, and 1.1, H-5'), 7.80 (1H, dt, $J 7.8$ and 1.0, H-3','), 7.82 (1H, td, $J$ 7.8, and 1.0, H-4',' ), 7.88 (1H, td, $J 7.9$ and 1.8, H-4' '), 7.91 (1H, td, $J 7.8$ and 1.8, H-4'), $7.96(1 \mathrm{H}, \mathrm{dt}, J$ 7.9, and 0.9, H-3' '), 8.27 (1H, dt, $J 7.8$ and 1.0, H-3'), 8.60 (1H, d, $J$ 1.6, H-5), 8.75 (1H, ddd, $J$ 4.8, 1.7 and 0.9, H-6' ’'), 8.83 (1H, ddd, $J$ 5.0, 1.8, and 0.9, H-6'”), 8.84 (1H, ddd, $J$ 5.0, 0.8, and 0.9, H-6'), and 8.91 (1H, d, $J 1.6, \mathrm{H}-7):{ }^{13} \mathrm{C}$ NMR $\delta$ 113.01, 123.14, 123.31, 123.45, 123.52, 124.84, 128.78, 131.98, 133.34, 135.73, 136.73, 137.16, 145.23, 145.65, 235.73, 146.87, 149.64, 149.84, 150.00, 153.21, 157.71, 158.26, 159.66, and 159.82; $\lambda_{\max } \mathrm{nm}$ $(\log \varepsilon) 298$ (5.02), 314 (4.95, sh), 365 (4.40), 378 (4.40), and 506 (3.74). Anal. Calcd for $\mathrm{C}_{24} \mathrm{H}_{15} \mathrm{~N}_{4} \mathrm{Cl}$ : C, 73.00; H, 3.83; N, 14.19. Found: C, 73.03; H, 4.09; N, 13.92.

\section{Reaction of 2-chloro-3-(2-pyridyl)-1-azaazulene (8a) with 2-pyridyllithium}

Under argon atmosphere, $1.5 \mathrm{M}$ butyllithium $(0.89 \mathrm{~mL}, 1,40 \mathrm{mmol})$ was added to the solution of 2-bromopyridine $(0.12 \mathrm{~mL}, 1.20 \mathrm{mmol})$ in dry THF $(15 \mathrm{~mL})$ at $-90{ }^{\circ} \mathrm{C}$. To the mixture $8 \mathrm{a}(0.150 \mathrm{~g}$, $0.62 \mathrm{mmol})$ in dry THF $(20 \mathrm{~mL})$ was added, and the mixture was stirred for $15 \mathrm{~min}$ at $-80{ }^{\circ} \mathrm{C}$, then $\mathrm{MeOH}(10 \mathrm{~mL})$ was added. After the mixture was warm to rt, $o$-chloranil $(0.260 \mathrm{~g}, 2.4 \mathrm{mmol})$ was added to the mixture and the mixture was stirred for $17 \mathrm{~h}$ at $50{ }^{\circ} \mathrm{C}$. The mixture was poured into water and extracted with $\mathrm{CHCl}_{3}$. The extract was dried over $\mathrm{Na}_{2} \mathrm{SO}_{4}$, and evaporated. The residue was chromatographed on silica gel column with EtOAc-hexane $(1:$ : $)$ to give 2-chloro-3,8-bis(2-pyridyl)-1-azaazulene 2-chloro-3,4-bis(2-pyridyl)-1-azaazulene (13a) (12a)

2-methoxy-3,8-bis(2-pyridyl)-1-azaazulene

(13b) $(0.058$ g, $30 \%)$,

2-methoxy-3,4-bis(2-pyridyl)-1-azaazulene (12b) (0.014 g, 7\%).

12a: Red brown prisms (from hexane- $\mathrm{CH}_{2} \mathrm{Cl}_{2}$ ), mp $179-182{ }^{\circ} \mathrm{C}:{ }^{1} \mathrm{H}$ NMR $\delta 6.92(1 \mathrm{H}$, ddd, $J$ 7.4, 4.9, 
and 0.9, H-5', ), 6.98 (1H, ddd, $J$ 7.6, 4.1, and 0.9, H-5'), 7.13 (1H, dt, $J 7.7$ and 0.9, H-3'), 7.15 (1H, dt, $J$ 7.7 and 0.9, H-3'’), 7.26 (1H, ddd, $J$ 7.7, 7.4, and 1.7, H-4'), 7.41 (1H, ddd, $J$ 7.7, 7.4 and 1.9, H-4'’), 7.88 (1H, dd, $J 9.8$ and 9.5, H-7), 7.95 (1H, dd, $J 10.1$ and 1.3, H-5), 8.01 (1H, ddd, $J$ 10.1, 9.5, and 1.0, H-6), 8.24 (1H, dd, $J 4.9$ and 1.9, H-6'), 8.34 (1H, dd, $J 4.9$ and 1.7, H-6'’), and 8.78 (1H, dd, $J 9.8$ and 1.0, H-8): ${ }^{13} \mathrm{C}$ NMR $\delta 119.64,121.33,122.55,124.42,125.02,129.48,133.72,134.04,136.11,136.34$, 139.28, 146.45, 147.80, 147.83, 151.94, 156.21, 157.05, and 157.49; $\lambda_{\max } \mathrm{nm}(\log \varepsilon) 290$ (4.60), 338 (3.83, sh), and 490 (3.20). Anal. Calcd for $\mathrm{C}_{19} \mathrm{H}_{12} \mathrm{~N}_{3} \mathrm{Cl}$ : C, 71.81; H, 3.81; N, 13.22. Found: C, 71.70; H, 3.87; N, 13.31.

13a: Orange powders (from hexane- $\mathrm{CH}_{2} \mathrm{Cl}_{2}$ ), mp 197-198 ${ }^{\circ} \mathrm{C}:{ }^{1} \mathrm{H}$ NMR $\delta 7.33$ (1H, ddd, $J$ 6.8, 4.1, and 0.9, H-5' '), 7.42 (1H, ddd, $J$ 7.6, 4.1, and 0.9, H-5'), 7.77 (1H, dd, $J 10.1$ and 9.4, H-5), 7.89 (3H, m, H-3', 4', and H-4' '), 8.04 (1H, dd, $J$ 10.8, 9.7, and 0.8, H-6), 8.31 (1H, td, $J 8.9$ and 0.9, H-3'), 8.37 (1H, d, $J$ 10.8, H-7), 8.83 (1H, dd, $J 4.1$ and 0.9, H-6'), 8.85 (1H, dd, $J 4.3$ and 1.0, H-6' '), and 9.19 (1H, dd, $J 10.1$ and 0.8, H-4): ${ }^{13} \mathrm{C}$ NMR $\delta 120.80,121.38,122.52,124.44,127.63,129.48,133.01,134.80$, 135.09, 135.48, 137.14, 144.46, 145.35, 148.66, 148.71, 151.37, 154.50, and 156.15; $\lambda_{\max } \mathrm{nm}(\log \varepsilon)$ 276 (4.42), 314 (4.56), 348 (4.14, sh), and 496 (3.21). Anal. Calcd for $\mathrm{C}_{19} \mathrm{H}_{12} \mathrm{~N}_{3} \mathrm{Cl}$ : C, 71.81; $\mathrm{H}$, 3.81; N, 13.22. Found: C, 71.67; H, 3.98; N, 13.11.

12b: Orange powders (from hexane- $\mathrm{CH}_{2} \mathrm{Cl}_{2}$ ), mp 137-139 ${ }^{\circ} \mathrm{C}:{ }^{1} \mathrm{H} \mathrm{NMR} \delta 4.31\left(3 \mathrm{H}, \mathrm{s}, \mathrm{OCH}_{3}\right), 6.84(1 \mathrm{H}$, ddd, $J$ 7.5, 4.9, and 1.3, H-5' '), 6.93 (1H, ddd, $J$ 7.4, 4.9, and 1.3, H-5'), $7.10(1 \mathrm{H}, \mathrm{dt}, J 7.7$ and 0.9, H-3'), 7.13 (1H, dt, $J 7.9$ and 1.0, H-3'’), 7.21 (1H, td, $J$ 7.8, and 1.7, H-4'), 7.33 (1H, ddd, $J$ 7.7, 7.5 and 1.8, H-4'’), 7.66 (2H, m , H-5 and 7), 7.76 (1H, m, H-6), 8.19 (1H, ddd, J 4.9, 1.7, and 0.9, H-6'), 8.33 (1H, ddd, J 4.9, 1.7, and 0.9, H-6”'), and 8.41 (1H, m, H-8): ${ }^{13} \mathrm{C}$ NMR $\delta$ 56.64, 112.87, 119.89, 121.74, 125.05, 125.46, 130.21, 131.34, 132.54, 134.29, 134.77, 134.88, 140.77, 143.31, 148.56, 148.61, 153.09, 157.16, 159.72, and 173.93; $\lambda_{\max } \mathrm{nm}(\log \varepsilon) 290$ (4.56), 295 (4.56), 374 (3.75), 391 (3.77), and 466 (3.33). Anal. Calcd for $\mathrm{C}_{20} \mathrm{H}_{15} \mathrm{~N}_{3} \mathrm{O}: \mathrm{C}, 76.66 ; \mathrm{H}, 4.82 ; \mathrm{N}, 13.41$. Found: C, 69.63; H, 4.05; N, 11.59 .

13b: Orange powders (from hexane- $\left.\mathrm{CH}_{2} \mathrm{Cl}_{2}\right)$, mp 142-143 ${ }^{\circ} \mathrm{C}:{ }^{1} \mathrm{H} \mathrm{NMR} \delta 4.26\left(3 \mathrm{H}, \mathrm{s}, \mathrm{OCH}_{3}\right), 7.17(1 \mathrm{H}$, ddd, $J$ 7.8, 4.9, and 1.0, H-5'’), 7.35 (1H, ddd, $J$ 7.4, 4.2, and 1.0, H-5'), 7.61 (1H, dd, $J$ 10.4, 9.2 and 0.6, H-5), 7.71 1H, ddd, $J$ 10.8, 9.2 and 1.0, H-6), 7.76 (1H, ddd, $J$ 8.0, 7.8, and 1.9, H-4' '), 7.82 (1H, td, $J 7.4$ and 1.8, H-4'), 7.98 (1H, ddd, $J$ 8.0, 1.0, and 0.9, H-3'’), 8.15 (1H, d, $J$ 10.8, H-7), 8.31 (1H, ddd, $J$ 7.4, 1.0, and 0.9 and 1.0, H-3'), 8.77 (1H, ddd, $J$ 4.8, 1.8, and 0.9, H-6'’), 8.82 (1H, ddd, $J$ 4.2, 1.8, and 0.9 , H-6'), and 9.49 (1H, dd, $J 10.4$ and 1.0, H-4): ${ }^{13} \mathrm{C}$ NMR $\delta 56.95,110.11,120.94,123.00,124.42$, 128.78, 130.57, 133.26, 133.73, 134.01, 135.38, 136.56, 141.66, 146.32, 149.64, 152.40, 153.99, 158.98, and 173.40; $\lambda_{\max } \mathrm{nm}(\log \varepsilon) 279$ (4.32), 325 (4.49), 354 (4.08, sh), 394 (3.79), and 476 (3.39). Anal. Calcd for $\mathrm{C}_{20} \mathrm{H}_{15} \mathrm{~N}_{3} \mathrm{O}$ : C, 76.66; H, 4.82; N, 13.41. Found: C, 69.63; H, 4.05; N, 11.59.

\section{Reaction of 2-methoxy-3-(2-pyridyl)-1-azaazulene (8b) with 2-pyridyllithium}

Under argon atmosphere, $1.5 \mathrm{M}$ butyllithium $(0.48 \mathrm{~mL}, 0.75 \mathrm{mmol})$ was added to the solution of 2-bromopyridine $(0.064 \mathrm{~mL}, 0.68 \mathrm{mmol})$ in dry THF $(10 \mathrm{~mL})$ at $-90{ }^{\circ} \mathrm{C}$. To the mixture $8 \mathbf{b}(0.080 \mathrm{~g}$, $0.34 \mathrm{mmol})$ in dry THF $(15 \mathrm{~mL})$ was added, and the mixture was stirred for $15 \mathrm{~min}$ at $-80{ }^{\circ} \mathrm{C}$, then $\mathrm{MeOH}(10 \mathrm{~mL})$ was added. After the mixture was warm to $\mathrm{rt}, \mathrm{o}$-chloranil $(0.070 \mathrm{~g}, 0.68 \mathrm{mmol})$ was 
added to the mixture and the mixture was stirred for $17 \mathrm{~h}$ at $50{ }^{\circ} \mathrm{C}$. The mixture was poured into water and extracted with $\mathrm{CHCl}_{3}$. The extract was dried over $\mathrm{Na}_{2} \mathrm{SO}_{4}$, and evaporated. The residue was chromatographed on silica gel column with EtOAc-hexane $(1: 1)$ to give $\mathbf{1 3 b}(0.032 \mathrm{~g}, 30 \%)$ and $\mathbf{1 2 b}$ (0.028 g, 26\%).

\section{REFERENCES}

1. For reviews see, N. Abe, 'Recent Research Developments in Organic and Bioorganic Chemistry' 2001, 4, 14, Transworld Research Network.; T. Nishiwaki and N. Abe, Heterocycles, 1981, 15, 547; M. Kimura, Yuki Gosei Kagaku Kyokai Shi, 1981, 39, 690.

2. S. Wakabayashi, R. Uriu, T. Asakura, C. Akamatsu, and Y. Sugihara, Heterocycles, 2008, 75, 383.

3. M. Oda, K. Ogura, N. C. Thanh, S. Kishi, S. Kuroda, K. Fujimori, T. Noda, and N. Abe, Tetrahedron Lett., 2007, 48, 4471.

4. N. Abe, E. Hashimoto, H. Fujii, Y. Murakami, S. Tagashira, and A. Kakehi, Heterocycles, 2004, 63, 2341.

5. $\quad$ N. Abe, M. Tanaka, T. Maeda, H. Fujii, and A. Kakehi, Heterocycles, 2005, 66, 229. 